Article

\title{
Effect of Moderate Temperature Thermal Modification Combined with Wax Impregnation on Wood Properties
}

\author{
Jing-Wen Zhang ${ }^{1}$, Hong-Hai Liu ${ }^{1,2, * \mathbb{C}}$, Lin Yang ${ }^{1,2,3}$, Tian-Qi Han ${ }^{1}$ and Qin Yin ${ }^{1}$ \\ 1 College of Furnishings and Industrial Design, Nanjing Forestry University, Nanjing 210037, China; \\ WENNYZHANG96@163.com (J.-W.Z.); yanglin@njfu.edu.cn (L.Y.); Hantianqi9512@163.com (T.-Q.H.); \\ yanqiuhazel@163.com (Q.Y.) \\ 2 Co-Innovation Center of Efficient Processing and Utilization of Forest Resources, \\ Nanjing Forestry University, Nanjing 210037, China \\ 3 Key Laboratory of Bio-Based Material Science \& Technology (Northeast Forestry University), \\ Ministry of Education, Harbin 150040, China \\ * Correspondence: liuhonghai2020@njfu.edu.cn
}

Received: 30 October 2020; Accepted: 18 November 2020; Published: 20 November 2020

\begin{abstract}
Thermal modification (TM) improves the hydrophobicity, dimensional stability, and durability of wood, but TM commonly results in severe color change and mechanical strength loss as wood is treated at higher temperature. In this study, Pterocarpus macrocarpus Kurz wood was thermally modified at moderate temperature $\left(150{ }^{\circ} \mathrm{C}\right)$ and higher temperature $\left(200{ }^{\circ} \mathrm{C}\right)$, and subsequently $\mathrm{TM}$ wood at $150{ }^{\circ} \mathrm{C}$ was subjected to wax impregnation (WI), the effect of a combination of TM and WI on the hygroscopicity, dimensional stability, and mechanical properties, as well as the micro-structure of wood, were investigated and compared. The results showed that the mass loss of wood was slight at $150{ }^{\circ} \mathrm{C} \mathrm{TM}$, while it became severe at $200{ }^{\circ} \mathrm{C}$ TM conditions. TM conditions affected the amount of the subsequent wax impregnation; the equilibrium moisture content $(E M C)$, water absorption ratio, and adsorption and absorption swelling of the $150{ }^{\circ} \mathrm{C} \mathrm{TM}+$ WI group were lower than that of $200{ }^{\circ} \mathrm{C} \mathrm{TM}$, and presented the lowest value. Moderate temperature TM could improve the hydrophobicity and dimensional stability of wood, but WI played a key role in the improvement. TM decreased the modulus of rupture (MOR) of wood, while WI improved the MOR. TM increased the modulus of elasticity (MOE) of wood, but WI had little effect on MOE; Scanning electron microscope (SEM) observation showed that the wax was successfully impregnated into the wood interior, and presented an even distribution on the internal surfaces of wood cells; Fourier-transform infrared spectroscopy (FTIR) spectra verified the changes of $-\mathrm{OH}$ and $\mathrm{C}=\mathrm{O}$ after TM and TM + WI, which contributed to decreasing hygroscopicity and improving the dimensional stability of the wood. Impregnated wax improved wood mechanical strength, but decreased the lightness, and deepened the color of wood. The combination of thermal modification at moderate temperature with subsequent wax impregnation is a practical approach for improving wood properties.
\end{abstract}

Keywords: thermal modification; wax impregnation; hygroscopicity; dimensional stability; mechanical properties

\section{Introduction}

Wood is a natural and reproducible material. It has been widely used in constructions, buildings, and woodworks, due to its natural advantages, such as high strength-to-weight ratio, insulating properties, sound insulation performance, lack of electrical conductivity, and temperature stability. In contrast, wood also has natural defects, such as drying shrinkage, poor dimensional stability, 
and durability [1-3], limiting accordingly its extensive utilization. The amount of water, especially the bound water in wood, influences the dimensional stability, and physical and mechanical properties of wood-based products [4]. Wood mainly contains three components: cellulose, hemicellulose, and lignin. Wood hygroscopicity is mainly attributed to the strong hydrophilic capacity of hemicellulose $[5,6]$. Reducing the hygroscopicity of wood is an effective way to improve wood dimensional stability, durability, and hydrophobicity [7].

In order to increase the dimensional stability, durability, and hydrophobicity, against frequent use under natural environmental conditions, many modifications have been applied to wood to reduce the hygroscopicity, such as steam-heat modification [8], methyltrimethoxysilane modification [9], boron and compatibilizer modification [10], surface modification [11], impregnation modification [12], and thermal modification (TM) $[8,13,14]$. These modifications can be classified into chemical modification and physical modification. Chemical modification of wood can achieve good results for improving wood dimensional stability and hydrophobicity, however, the modifications might be environmentally detrimental. TM can successfully improve wood dimensional stability and durability by thermal degradation of hemicellulose $[15,16]$. TMs have been commercially applied to wood and are considered as an environmentally friendly method. However, after severe thermal modification, wood components undergo chemical degradation, which increases its brittleness, reduces its mechanical properties, and results in serious color deterioration [17,18], thereby, limiting the further application of TM wood. In addition, TM at higher temperature is a high energy-consuming process.

Wax is a good water repellent and suitable for wood protection [19], which can decrease water uptake rate and improve the dimensional stability of wood [20]. Wax is also an environmentally friendly material, and is cost-effective, abundant, and non-toxic [21]. Wax can be applied to wood in a melted state, diluted in organic solvents, or in the state of emulsions or suspensions via impregnation or combined with other treatments [22,23]. Wax impregnation consists of three major processes: first, microcrystalline wax is heated to liquid state, then the wood is impregnated with hot wax fluid, either with or without pressure, and the final process is the solidification of the microcrystalline wax in cell cavities and the intercellular space of the wood. The hygroscopicity and water absorption of wood are reduced after wax fills the cell cavity [24,25], thereby improving the dimensional stability of wood for long-term service life. In contrast to TM, wax impregnation may increase wood mechanical properties [26], and maintain the natural color and texture of wood [27].

Both TM and WI are environmentally friendly treatments of wood. The combined treatments may further improve wood properties, against the effect of water, and the mechanical strength [28], and also might reduce processing energy consumption. However, the normal procedure for the combination is that wax is impregnated first, and subsequently subjected to higher temperature TM, which results in the same shortcomings as TM for wood. A few studies have been conducted with the opposite procedure $[29,30]$, but the temperature of TM was higher. This might lead to severe color change, strength loss, and higher energy consumption.

In the current study, the combined treatment of TM and WI was carried out for Pterocarpus macrocarpus Kurz wood. Specimens were thermally modified at $150{ }^{\circ} \mathrm{C}$ (moderate temperature), and half of the thermal modification wood (TMW) was subsequently treated by WI at low temperature and at atmospheric conditions. The hygroscopicity, dimensional stability, and mechanical properties, as well as the micro-structure of the wood, after moderate-temperature TM and low-temperature WI were compared with the TMW after higher temperature treatment. The effects on the wood properties were systematically investigated to provide a practical support for the application to wood of moderate TM combined with WI. 


\section{Materials and Methods}

\subsection{Materials}

Air-dried Pterocarpus macrocarpus Kurz heartwood was used, the average moisture content (MC) was $10 \%$ and specific gravity (SP) was 0.84 . The initial sizes of the boards were $1000 \mathrm{~mm} \times 100 \mathrm{~mm} \times$ $25 \mathrm{~mm}(\mathrm{~L} \times \mathrm{T} \times \mathrm{R})$. They were produced into specimens of $300 \mathrm{~mm} \times 20 \mathrm{~mm} \times 20 \mathrm{~mm}$, and $20 \mathrm{~mm}$ $\times 20 \mathrm{~mm} \times 20 \mathrm{~mm}(\mathrm{~L} \times \mathrm{T} \times \mathrm{R})$ by Degoo Furniture Co., Ltd., Xianyou, China. Specimens without knots and other defects were used for the TM and WI experiments. Microcrystalline wax (Sinopec), used for the impregnation test, was also supplied by the same company. The properties of the wax were: melting point $\left(60^{\circ} \mathrm{C}\right)$, molecular weight (500-800 g), refractive index (1.435-1.445), kinematic viscosity at $99{ }^{\circ} \mathrm{C}(9.2-25.0 \mathrm{~mm} 2 / \mathrm{s})$, and density $(0.80-0.92 \mathrm{~g} / \mathrm{mL})$.

\subsection{Equipment}

The main device for TM was a heat treatment chamber with a pressure controlling device (HJ-ZK60, Dongguan Hengjun Instrument Equipment Co., Ltd., Dongguan, China). Other equipment included an electronic balance (JA21002, Shanghai Liangping Instrument and Meter Co., Ltd., Shanghai, China; 1200 g/1 mg); an electric heating oven (DHG-905386-III, Shanghai Cimo Medical Instrument Co., Ltd., Shanghai, China); and a Vernier caliper (CD-20CPX, Mitutoyo, Japan, 0-200 mm/0.01 mm).

\subsection{Thermal Modification and Thermal Modification Combined with Wax Impregnation}

All specimens were first dried at $103 \pm 2{ }^{\circ} \mathrm{C}$ to constant weight according to GB/T 1931-2009. Thereafter, the specimens were randomly grouped into two TMs and one control. For the $150{ }^{\circ} \mathrm{C} \mathrm{TM}$ test, there were 14 specimens of each size under each experimental condition; for the $200{ }^{\circ} \mathrm{C} \mathrm{TM}$ test, there were 7 specimens of each dimension; and for the control group, there were also 7 specimens of each dimension. A previous study reported that thermal modification under vacuum has obvious advantages in wood property improvement [31]. In the current experiments, TMs were therefore subsequently carried out under vacuum conditions. As shown in Table 1, specimens were first pre-heated in the vacuum chamber for $1 \mathrm{~h}$, then the temperature was increased to the setting values, and then maintained at this temperature and heating time, as specified by the designed schedules. The heating processes were designed at two temperatures of $150{ }^{\circ} \mathrm{C}$ and $200^{\circ} \mathrm{C}$, and different heating times of $2 \mathrm{~h}$, and $6 \mathrm{~h}$ at $13.4 \mathrm{kPa}$. After the heating processes, specimens were cooled in the chamber at $100{ }^{\circ} \mathrm{C}$ and $13.3 \mathrm{kPa}$ for $1 \mathrm{~h}$. Thereafter, $50 \%$ of the $150{ }^{\circ} \mathrm{C} \mathrm{TM}$ specimens ( 7 replicates) were impregnated in a stainless steel tank filled with melted microcrystalline wax $\left(90^{\circ} \mathrm{C}\right)$. The weights of a total of 6 specimens were measured every $8 \mathrm{~h}$ during the wax impregnation process until the weight became constant after $48 \mathrm{~h}$. Then, the waxes on the wood surfaces were wiped, and the specimens were placed in sealed plastic bags for $1 \mathrm{~h}$ cooling at $30^{\circ} \mathrm{C}$.

Table 1. Experimental parameters for thermal modification (TM) and wax impregnation (WI) process.

\begin{tabular}{ccccc}
\hline Treating & Process & Temperature $\left({ }^{\circ} \mathbf{C}\right)$ & Heating Time (h) & Pressure (kPa) \\
\hline \multirow{2}{*}{ TM } & Preheating & 100 & 1 & 13.4 \\
& Heating & $150 / 200$ & $2 / 6$ & 13.4 \\
& Cooling & 100 & 1 & 13.4 \\
WI & Impregnation & 90 & 48 & 101.3 \\
& Cooling & 30 & 1 & 101.3 \\
\hline
\end{tabular}

\subsection{Mass Loss and Weight Percentage Gain of Wood}

The mass loss $(M L)$ of the specimens was attributed to heating temperature and duration, while the weight percentage gain (WPG) of the specimens was due to wax being impregnated into wood 
during the immersion process. The $M L$ and WPG of specimens were calculated using Equations (1) and (2), and 7 specimens of $20 \mathrm{~mm} \times 20 \mathrm{~mm} \times 20 \mathrm{~mm}(\mathrm{~L} \times \mathrm{T} \times \mathrm{R})$ were measured for each condition.

$$
\begin{gathered}
M L=\left(M_{\mathrm{o}}-M_{1}\right) / M_{\mathrm{o}} \times 100 \% \\
W P G=\left(M_{\mathrm{i}}-M_{1}\right) / M_{\mathrm{h}} \times 100 \%
\end{gathered}
$$

where $M_{\mathrm{o}}$ is the absolute dry weight of specimens prior to thermal modification, $M_{1}$ is the absolute dry weight of specimens after thermal modification, and $M_{\mathrm{i}}$ is the weight of specimens after wax impregnation.

\subsection{Water Adsorption and Water Absorption Tests}

A total of 49 specimens of $20 \mathrm{~mm} \times 20 \mathrm{~mm} \times 20 \mathrm{~mm}(\mathrm{~L} \times \mathrm{T} \times \mathrm{R})$ were tested for water adsorption and water absorption. They were divided into 7 groups, including two $150{ }^{\circ} \mathrm{C}$ TM groups, two 150 ${ }^{\circ} \mathrm{C}$ TM plus wax impregnation groups $\left(150{ }^{\circ} \mathrm{C} \mathrm{TM}+\mathrm{WI}\right)$, two $200^{\circ} \mathrm{C}$ TM groups, and one control group, each group containing 7 specimens. Before the water adsorption tests, all specimens were first dried at $103 \pm 2{ }^{\circ} \mathrm{C}$ to absolute dry conditions, and then the absolute dry weight was measured using an electronic balance (JA21002), and dimensions were measured in the tangential and radial directions using a digital caliper (CD-20CPX). Thereafter, they were treated in a constant temperature and humidity conditioning chamber at $20{ }^{\circ} \mathrm{C}$ and $65 \%$ relative humidity (RH), the weight of the selected specimens was measured according to GB/T 1931-2009, until their weights became constant and reached equilibrium moisture content $(E M C)$. The weights and dimensions of all specimens were recorded, and then they were dried at $103 \pm 2{ }^{\circ} \mathrm{C}$ again to constant weight, after that the absolute dry weights and dimensions were measured again. Finally, they were put into a plastic box filled with distilled water for water absorption, similarly to the water adsorption test, the weights of selected specimens were measured until their weights became constant, then the final weights and sizes of all water-saturated specimens were measured following the above procedures, after cleaning the water on the surfaces. The water adsorption and water absorption capacity were evaluated by EMC and water absorption ratio (W), and were calculated using Equations (3) and (4). The dimensional stability of the wood was estimated by swelling of specimens after the water adsorption and water absorption tests, and was calculated using Equation (5).

$$
E M C=\left(M_{\mathrm{e}}-M_{\mathrm{o}}\right) / M_{\mathrm{o}} \times 100 \%
$$

where $E M C$ is $M C$ of the specimen after conditioning, $M_{\mathrm{e}}$ is the weight after conditioning, and $M_{\mathrm{o}}$ is the absolute dry weight.

$$
W=\left(M_{1}-M_{\mathrm{o}}\right) / M_{\mathrm{o}} \times 100 \%
$$

where $W$ is water absorption ratio, $M_{1}$ is the weight of the water-saturated specimen, and $M_{\mathrm{o}}$ is the weight of the absolute dry specimen.

$$
S=\left(L_{1}-L_{\mathrm{o}}\right) / L_{\mathrm{o}} \times 100 \%
$$

where $S$ is the tangential or radial swelling, $L_{1}$ is water adsorption or water absorption dimension, and $L_{\mathrm{O}}$ is the absolute dry dimension.

\subsection{Modulus of Rupture (MOR) and Modulus of Elasticity (MOE) of Wood}

The MOR and MOE tests were carried out based on the GB/T 1936.1-2009 national standard. Prior to testing, all specimens were treated in a constant temperature and humidity conditioning chamber at $20{ }^{\circ} \mathrm{C}$ and $65 \%$ relative humidity (RH). After the weight became constant, specimens $(300 \mathrm{~mm} \times 20 \mathrm{~mm}$ $\times 20 \mathrm{~mm}, \mathrm{~L} \times \mathrm{T} \times \mathrm{R}$ ) were subjected to a bending test machine (Shimadzu, Kyoto, Japan). The MOR 
and MOE of the treated and control specimens were tested, and the average values of 7 replicates of each group were compared in this study.

\subsection{Scanning Electron Microscopy (SEM) Observation of the TM + WI Modified Wood}

To observe the distributions of wax impregnation, three samples of $150^{\circ} \mathrm{C} / 6 \mathrm{~h}$ WI with dimensions of $5 \mathrm{~mm} \times 5 \mathrm{~mm} \times 5 \mathrm{~mm}(\mathrm{~L} \times \mathrm{T} \times \mathrm{R})$ were prepared, and which were cut from the central part of the specimens of $20 \mathrm{~mm} \times 20 \mathrm{~mm} \times 20 \mathrm{~mm}(\mathrm{~L} \times \mathrm{T} \times \mathrm{R})$. Meanwhile, three thin slices were cut from the cross sections of the TM + WI samples. Thereafter, the control and TM + WI samples, as well as the thin slices, were fixed on conductive adhesives and then were dried in a freeze dryer to a constant weight, and finally they were coated with gold. The micro-transverse surfaces of the control and TM + WI samples were observed by SEM (FEI Quanta 200, Netherland).

\subsection{Fourier Transform Infrared Spectroscopy (FTIR) Characterization}

Powders of 200-mesh-size of the control and the treated specimens were prepared separately and then mixed using $\mathrm{KBr}$ pellets at the ratio of 1:100 (by weight). FTIR was conducted using a standard FTIR spectroscope (VERTEX $80 \mathrm{v}$, Bruker, Germany). Spectra were measured in the transmission mode, and the spectral resolution was $4 \mathrm{~cm}^{-1}$ with 16 scans in the $4000-400 \mathrm{~cm}^{-1}$ region [32].

\subsection{Statistical Analysis}

Analyses of variance (ANOVA) by SPSS were applied to the data to assess the influences of the modifications on the wood properties. Duncan's multiple range tests $(p<0.05)$ were further applied to separate the differences between mean values of each modification level. The treatment conditions were independent variables, and the EMC, W, swelling, and MOR and MOE represent dependent variables in the statistical analysis.

\section{Results and Discussion}

\subsection{Mass Loss and Weight Percentage Gain of Wood}

The $M L$ of specimens after $\mathrm{TM}$ at $150{ }^{\circ} \mathrm{C}$ and $200^{\circ} \mathrm{C}$, and the $W P G$ of the $150{ }^{\circ} \mathrm{C} \mathrm{TM}$ specimens after WI are presented in Table 2. It can be seen that the $M L$ was small in the moderate temperature of the $150{ }^{\circ} \mathrm{C}$ condition. The $M L$ was only $0.79 \%$ after $2 \mathrm{~h} \mathrm{TM}$, and $1.45 \%$ after $6 \mathrm{~h}$ TM. However, the $M L$ became severe at $200{ }^{\circ} \mathrm{C} \mathrm{TM}$ conditions. The $M L$ of specimens after $200{ }^{\circ} \mathrm{C} / 2 \mathrm{~h}$ TM was 2.2 times as much as that after $150^{\circ} \mathrm{C} / 6 \mathrm{~h} \mathrm{TM}$, indicating that the $M L$ was affected more obviously by temperature. The ratios of $M L$ of specimens after $6 \mathrm{~h} \mathrm{TM}$ to after $2 \mathrm{~h}$ TM were 1.83 times and 1.32 times for $150^{\circ} \mathrm{C}$ and $200{ }^{\circ} \mathrm{C}$ conditions, respectively; this suggests that the effect of modification time was greater in the moderate temperature ranges, and became weak at higher temperature conditions. The $M L$ increased obviously with temperature and modification time, while the temperature played a critical role in the $M L$ of the wood. The weights of the $6 \mathrm{~h}$ and $2 \mathrm{~h}$ TM specimens after WI increased $13.57 \%$ and $10.61 \%$, respectively. The WPG of the $6 \mathrm{~h}$ TM specimens increased by about $27.90 \%$ compared with the of $2 \mathrm{~h}$ TM specimens. These findings indicate that wax was successfully impregnated into the TM specimens, and that TM time affected the WPG of TM specimens.

Table 2. Mass loss $(M L)$ and weight percentage gain (WPG) of wood after TM and WI.

\begin{tabular}{cccc}
\hline Temperature $\left({ }^{\circ} \mathbf{C}\right)$ & Time(h) & ML (\%) after TM & WPG (\%) after WI \\
\hline \multirow{2}{*}{150} & 2 & $0.79(0.19)$ & $10.61(0.26)$ \\
& 6 & $1.45(0.18)$ & $13.57(0.78)$ \\
200 & 2 & $3.16(0.40)$ & - \\
& 6 & $4.16(0.46)$ & - \\
\hline
\end{tabular}

Note: - means no wax impregnation. 


\subsection{Effect of Thermal Modification and Wax Impregnation on Water Adsorption and Water Absorption of Wood}

The EMC, which indicates the capacity for water adsorption, and the $W$ which demonstrates the capacity for water absorption, are shown in Figure $1 \mathrm{a}, \mathrm{b}$, respectively. In contrast to the control group, the EMC decreased obviously after TM and TM + WI, and the EMC of the TM + WI groups presented the lowest values. In contrast to the control group, the $E M C$ of the $150{ }^{\circ} \mathrm{C} / 2 \mathrm{~h}$ and $150{ }^{\circ} \mathrm{C} / 6 \mathrm{~h}$ TM specimens decreased by $10.87 \%$ and $16.94 \%$, respectively, while the $200{ }^{\circ} \mathrm{C} / 2 \mathrm{~h}$ and $200{ }^{\circ} \mathrm{C} / 6 \mathrm{~h}$ TM specimens decreased by $28.32 \%$ and $36.16 \%$. These results show that TM decreased the EMC of the wood, and the reduction became greater due to more severe TM, which is in agreement with a previous study [33]. However, after WI the EMC decreased by $69.40 \%$ and $73.58 \%$ for the $150{ }^{\circ} \mathrm{C} / 2 \mathrm{~h}$ and $150{ }^{\circ} \mathrm{C} / 6 \mathrm{~h}$ TM specimens, presenting the lowest values in the study. Compared with the EMC of the 200 ${ }^{\circ} \mathrm{C} / 6 \mathrm{~h}$ TM specimens, the EMC decreased by almost half after WI. These results suggest that WI further decreased the capacity of the wood water adsorption. Compared with the control group, the EMC of the $150{ }^{\circ} \mathrm{C} / 2 \mathrm{~h}$ and $150{ }^{\circ} \mathrm{C} / 6 \mathrm{~h}$ TM specimens decreased by $10.87 \%$ and $16.94 \%$, respectively, while the $150{ }^{\circ} \mathrm{C} / 2 \mathrm{~h}$ and $6 \mathrm{~h}$ TM specimens after WI decreased by $69.40 \%$ and $73.58 \%$, thus, the contribution of WI to the reduction of EMC was $58.53 \%$ and $56.64 \%$, respectively. The contribution of WI to the reduction of the EMC of the wood was 5.38 times and 3.34 times compared to TM, at $150{ }^{\circ} \mathrm{C} / 2 \mathrm{~h}$ and $150^{\circ} \mathrm{C} / 6 \mathrm{~h}$. The results suggest that wax impregnation played a dominant role in reducing wood water adsorption capacity, due to a large volume of wax being impregnated into the wood.
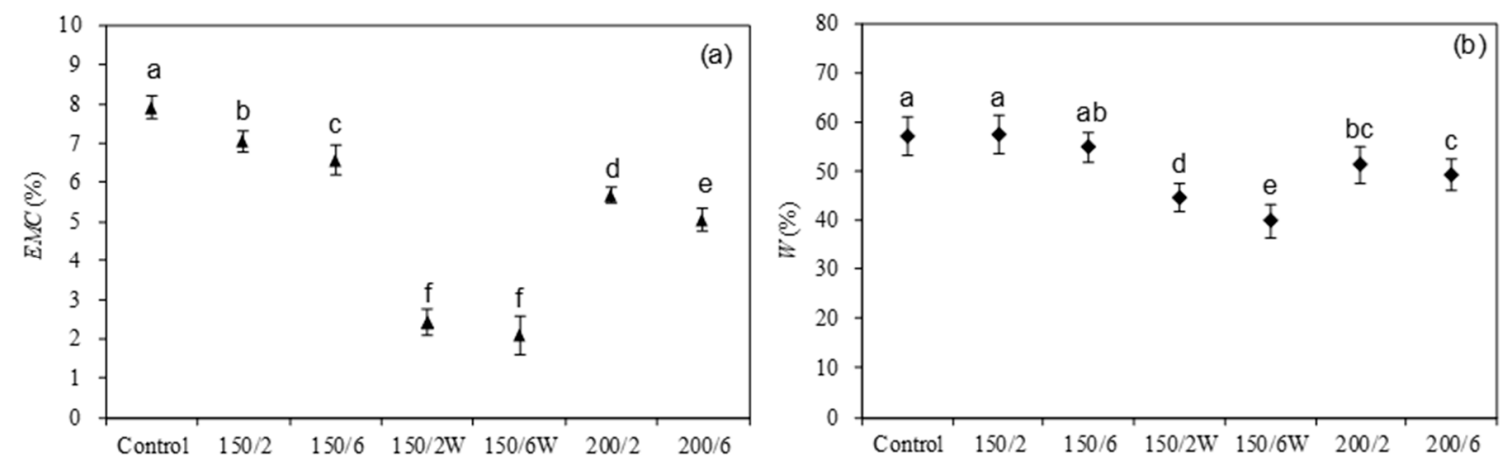

Figure 1. EMC and water absorption ratio $(W)$ of control and modified groups: water adsorption (a) and water absorption (b). Bars showing different letters indicate significant difference $(p<0.05)$ according to Duncan's multiple range tests.

The $W$, water absorption ratio, was much greater than that of the EMC for all groups, indicating that more water was absorbed into the wood. No significant differences were found in $W$ between the control group and the groups after $150{ }^{\circ} \mathrm{C} / 2 \mathrm{~h}$ and $150{ }^{\circ} \mathrm{C} / 6 \mathrm{~h} \mathrm{TM}$. Compared with the control group, the $W$ of the specimens after $200{ }^{\circ} \mathrm{C} / 2 \mathrm{~h}$ and $200^{\circ} \mathrm{C} / 6 \mathrm{~h} \mathrm{TM}$, and the specimens of $150{ }^{\circ} \mathrm{C} / 2 \mathrm{~h}$ and $150{ }^{\circ} \mathrm{C} / 6 \mathrm{~h} \mathrm{TM}+\mathrm{WI}$, presented significant differences. In contrast to the control group, the $W$ of specimens decreased by $13.45 \%$ after $200{ }^{\circ} \mathrm{C} / 6 \mathrm{~h} \mathrm{TM}$, and $29.94 \%$ after $150{ }^{\circ} \mathrm{C} / 6 \mathrm{~h} \mathrm{TM}+\mathrm{WI}$, while the $W$ of the specimen after $150{ }^{\circ} \mathrm{C} / 6 \mathrm{~h}$ TM barely changed. These results indicate that the WI could reduce the capacity of wood water absorption to a greater extent. The reduced $W$ may have been caused by the wax, which impregnates fully or partly into cell lumens, occupying some space, and also forms wax films attached to wood cell walls. Consequently, the spaces of the cell lumens for water absorption were reduced, and the free water migration path was blocked due to the hydrophobic property of wax films [29].

\subsection{Effect of Thermal Modification and Wax Impregnation on Swelling of Wood}

Figure 2 shows the tangential and radial swellings after water adsorption and absorption. The tangential and radial swellings of the modified groups were smaller than the control group, and the swellings showed a similar trend in both a tangential and radial direction. There were significant 
differences $(p<0.05)$ in adsorption swelling (Figure 2a) between the control and modified groups, indicating TM and TM + WI can both improve wood dimensional stability. Compared with the control group, the maximum reduction of swelling in the tangential direction was about $18.37 \%, 40.31 \%$, and $71.94 \%$; while in radial direction it was $15.48 \%, 48.39 \%$, and $67.10 \%$, for $150{ }^{\circ} \mathrm{C} \mathrm{TM}, 200{ }^{\circ} \mathrm{C} \mathrm{TM}$, and $150^{\circ} \mathrm{C} \mathrm{TM}+\mathrm{WI}$, respectively. The dimensional stability of the wood was largely improved after $200{ }^{\circ} \mathrm{C}$ TM and $150{ }^{\circ} \mathrm{C} \mathrm{TM}+\mathrm{WI}$. The swelling of the wood after $150^{\circ} \mathrm{C} \mathrm{TM}+\mathrm{WI}$ had the smallest value, indicating this had the best dimensional stability. In contrast to the $150^{\circ} \mathrm{C}$ TM group, swellings were decreased maximally by $53.57 \%$ and $51.62 \%$, in the tangential and radial direction, respectively, after WI. These results indicate that WI played a key role in the reduction of wood adsorption swelling, and the influence of WI on improving dimensional stability was bigger than TM. Generally, the swelling of the wood in the tangential direction was about two times as great as that in the radial direction. However, the difference of swelling in the tangential and radial direction of the $150{ }^{\circ} \mathrm{C} \mathrm{TM}+\mathrm{WI}$ group became smaller, and they were almost same (Figure 2a). These suggest the wood swelling property was extremely influenced by wax impregnation, which improved the wood dimensional stability significantly.
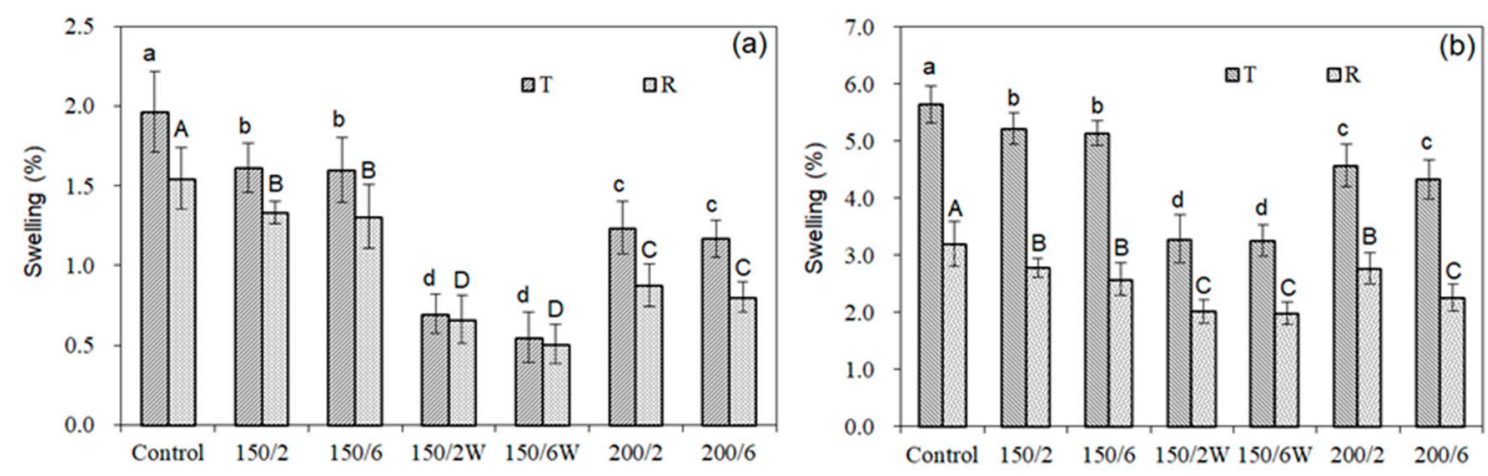

Figure 2. Water adsorption swelling (a) and water absorption swelling (b) of the control and modified groups in the tangential and radial direction. Bars showing different letters demonstrate significant difference $(p<0.05)$ according to Duncan's multiple range tests.

Similarly to the effects on water adsorption swelling, the absorption swelling of the modified groups reduced significantly $(p<0.05)$, contrasting with the control group. The absorption swelling presented the same tendency as the adsorption swelling, that the $150^{\circ} \mathrm{C} \mathrm{TM}+\mathrm{WI}$ group had the lowest swelling, followed by the $200^{\circ} \mathrm{C}$ TM group and the $150^{\circ} \mathrm{C}$ TM group. This indicates that, not only $\mathrm{TM}$, but also WI, increased the absorption dimensional stability of the wood. In contrast to the control group and the $150^{\circ} \mathrm{C} \mathrm{TM}$ group, the swelling at $150{ }^{\circ} \mathrm{C} \mathrm{TM}+\mathrm{WI}$ was significantly decreased after wax impregnation. This indicates that WI had a dominant influence on improving the dimensional stability of the wood. The decreased swelling via WI was mainly attributed to the bulking effect of the long hydrophobic chains of wax [27]. The capacity for water absorption decreased after TM and TM + WI, consequently the deformation resistance of the wood increased. Compared with the water adsorption swelling of the $150{ }^{\circ} \mathrm{C} \mathrm{TM}+$ WI group (Figure 2a), the tangential absorption swelling was seemingly greater than the radial swelling (Figure $2 b$ ). However, the difference of absorption swelling between the tangential and radial direction was smaller compared with the control group and TM groups.

\subsection{Effect of Thermal Modification and Wax Impregnation on Bending Strength (MOR) and Bending Stiffness (MOE) of Modified Wood}

Figure 3 shows the MOR and MOE of the control and modified wood. Compared with the control group, the MOR of the $150{ }^{\circ} \mathrm{C} / 6 \mathrm{~h}$ and $200{ }^{\circ} \mathrm{C} / 6 \mathrm{~h}$ TM groups decreased by $12.78 \%$ and $33.48 \%$, respectively, indicating that the MOR was influenced significantly $(p<0.05)$ by TM temperature. This result is consistent with the previous findings [30,31]. The decrease of MOR was due to the degradation of hemicellulose and the evaporation of extractives because of the high temperature 
during TM [34]. However, for the same TM temperature, no significant differences $(p<0.05)$ were found in MOR between groups with the same treating temperature, indicating treatment time has little effect on the bending strength of wood. For the $150^{\circ} \mathrm{C} \mathrm{TM}+\mathrm{WI}$ group, the MOR of the $150{ }^{\circ} \mathrm{C} \mathrm{TM}$ specimens increased significantly after WI. The MOR of the $150^{\circ} \mathrm{C} \mathrm{TM}+$ WI group was almost same as the control group (significant difference was not found, $p<0.05$ ). This shows that WI improved the wood bending strength significantly. The bending stiffness (MOE) of wood after TM increased significantly with temperature $(p<0.05)$ compared with the control group, which is in agreement with previous reports [35,36]. However, the treatment time had no significant effect $(p<0.05)$ on MOE in the same temperature conditions. Significant difference of MOE between the $150{ }^{\circ} \mathrm{C}$ TM group and $150^{\circ} \mathrm{C} \mathrm{TM}+\mathrm{WI}$ group was not observed, indicating WI has little effect on wood bending stiffness.
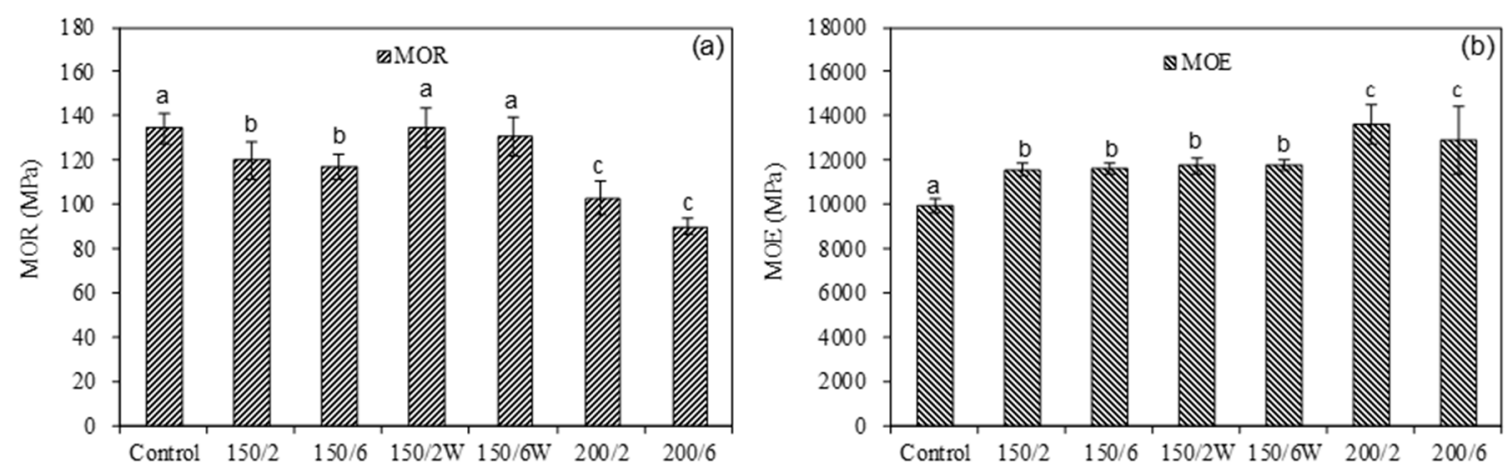

Figure 3. MOR (a) and MOE (b) of the control and modified groups. Bars showing different letters indicate significant difference $(p<0.05)$ according to Duncan's multiple range tests.

\subsection{Effect of Thermal Modification and Wax Impregnation on the Morphological Property of the} TM + WI Wood

Figure 4 shows features of the wood in cross section of the un-treated specimen, and the distribution of the impregnated wax in cross sections within the wood. As can be seen, wax covered most of the transversal sections of the cell lumens except the vessels, and presented a massive distribution as obvious shaped droplets (red arrows in Figure $4 b, c$ ); the overall distribution of the shaped droplet wax was more clear and even in Figure 4c. Additionally, Figure 4c shows thin layers of wax (red circles) formed after impregnation, which attached to the perforation plates of vessels with a uniform distribution. All SEM images show that wax was impregnated into the wood interior successfully, and presented even distributions on the internal surfaces of the wood cells, which played a dominant role in the improvement of the hydrophobicity, dimensional stability, and the mechanical strength of the wood.


Figure 4. SEM observations of the control samples (a), wax impregnated samples (b), and cutting slices (c). Red arrows indicate wax with shaped droplets, and red circles show the layers of wax formed. 


\subsection{Effect of Thermal Modification and Wax Impregnation on Chemical Changes of Wood}

The FTIR spectra of the control and modified samples, and the chemical compositions of the characteristic peaks, are shown in Figure 5 . The peak at $3400 \mathrm{~cm}^{-1}$ indicates $-\mathrm{OH}$, which influenced the MC of the wood and represents cellulose. The peak of $2900 \mathrm{~cm}^{-1}$ is the aliphatic $\mathrm{C}-\mathrm{H}$ vibration peak, and is the characteristic peak of cellulose. The $1700 \mathrm{~cm}^{-1}$ peak represents the $\mathrm{C}=\mathrm{O}$ stretching vibration, which is associated with hemicelluloses. The wavelengths of peaks at 1600, 1500, and 1430 $\mathrm{cm}^{-1}$ are related to the characteristic peak of lignin. Contrasting to the control group, the chemical structures of the TM and TM + WI specimens were modified. The reduction of the intensity of $-\mathrm{OH}$ absorption peak at $3400 \mathrm{~cm}^{-1}$ indicates that TM and TM + WI decreased the relative content of hydroxyl in the wood. Compared with the $150{ }^{\circ} \mathrm{C}$ TM group, the band intensity of $150{ }^{\circ} \mathrm{C} \mathrm{TM}+\mathrm{WI}$ at 3400 $\mathrm{cm}^{-1}$ related to $-\mathrm{OH}$ stretching increased, indicating that WI influences the hydroxyl group of TM wood. These results can explain why the wood dimensional stability was improved after TM and WI. The peaks at $2917 \mathrm{~cm}^{-1}$ and $2849 \mathrm{~cm}^{-1}$ of the $150{ }^{\circ} \mathrm{C} \mathrm{TM}+$ WI samples were obviously different from the others, showing typical absorption peaks of a $\mathrm{C}-\mathrm{H}$ bond, which are the characteristic peaks of saturated alkanes of wax. This indicates that wax was successfully impregnated into the wood.



Figure 5. FTIR spectra of control and modified samples.

In contrast to the control group, the intensity of the TM groups at $1700 \mathrm{~cm}^{-1}$ peak, which corresponds to $\mathrm{C}=\mathrm{O}$ increased, indicating thermal degradation of hemicellulose occurred after TM. However, the intensity of the $\mathrm{C}=\mathrm{O}$ stretching vibration changed little after $\mathrm{WI}$, comparing the $150{ }^{\circ} \mathrm{C}$ TM group with the $150^{\circ} \mathrm{C} \mathrm{TM}+$ WI group. The intensity of the stretching vibration of peaks at 1600 , 1500 , and $1430 \mathrm{~cm}^{-1}$ of the TM groups increased with temperature, indicating condensation and an oxidation reaction occurred in the process of $\mathrm{TM}$, and more stable compounds with benzene ring groups were formed. For the $150{ }^{\circ} \mathrm{C} \mathrm{TM}+\mathrm{WI}$ group, the intensity of the stretching vibration of these peaks increased after WI, suggesting that WI could improve the stability of wood structures. Furthermore, the increase in the number of single and double bonds leads to the generation of more electron conjugated systems, which greatly increases the absorption of visible light, decreases the lightness, and deepens the color of wood.

In addition, the intensity of the stretching vibration of peaks at $1030 \mathrm{~cm}^{-1}$, which is the characteristics peak of $\mathrm{C}-\mathrm{O}$ corresponding to cellulose and hemicellulose, decreased after TM and TM + WI. The $\mathrm{C}-\mathrm{O}$ bonds were selectively activated and produced carbohydrates, such as glucose, glucose 
derivatives, xylose, arabinose, etc., which are degraded during the high temperature TM, thus further reducing the capacity for moisture adsorption, and improving wood dimensional stability.

\section{Conclusions}

Pterocarpus macrocarpus Kurz wood was thermally modified at $150^{\circ} \mathrm{C}$ and $200{ }^{\circ} \mathrm{C}$, and subsequently moderate temperature $\left(150^{\circ} \mathrm{C}\right) \mathrm{TM}$ specimens were impregnated with wax. The effect of $\mathrm{TM}$ and $\mathrm{TM}+$ WI on the wood properties related to water, mechanical strength, and the micro-structure of the wood were studied. Conclusions were drawn as below:

1. Mass loss $(M L)$ of wood at the moderate temperature condition was small, and became obvious at the $200^{\circ} \mathrm{C}$ condition. The weight percentage gain $(W P G)$ of the $150^{\circ} \mathrm{C} / 6 \mathrm{~h}$ TM group was greater than that of the $150{ }^{\circ} \mathrm{C} / 2 \mathrm{~h}$ TM group.

2. TM time affected the amount of wax impregnation; $E M C$ of $150{ }^{\circ} \mathrm{C} \mathrm{TM}+\mathrm{WI}$ group was the lowest among the control and modified groups. Moderate TM decreased the EMC of the wood, but the WI played a key role in the reduction of $E M C$, which was 5.38 times and 3.34 times the contribution of TM at $150{ }^{\circ} \mathrm{C} / 2 \mathrm{~h}$ and $150{ }^{\circ} \mathrm{C} / 6 \mathrm{~h}$, respectively; In contrast to the $150{ }^{\circ} \mathrm{C} \mathrm{TM}$ group, adsorption swellings decreased maximally by $53.57 \%$ and $51.62 \%$ in the tangential and radial directions, respectively, after WI. WI played a dominate role for reduction of wood adsorption swelling, and the WI improvement on dimensional stability was bigger than TM. The absorption swelling of the modified groups presented the same tendency as the adsorption swelling; the $150^{\circ} \mathrm{C} \mathrm{TM}+\mathrm{WI}$ group had the lowest absorption swelling value.

3. The MOR of the thermally modified groups were all decreased, however, the MOR of the $150^{\circ} \mathrm{C}$ TM group was increased after WI, presenting almost the same value as the control group. The MOE of all modified groups were increased in this study; wax was successfully impregnated into the wood, and presented a uniform distribution on the internal surfaces of the wood cells.

4. The chemical composition and micro-structure of the wood were modified after TM and WI treatment. TM and TM + WI decreased the relative content of $-\mathrm{OH}$ and $\mathrm{C}=\mathrm{O}$ in the wood, which decreased hygroscopicity and improved the dimensional stability of the wood. WI improved the wood mechanical strength, but decreased the lightness and deepened the color of the wood. The combination of moderate temperature thermal modification combined with subsequent wax impregnation is a practical approach for improving wood properties.

Author Contributions: Conceptualization, H.-H.L. and L.Y.; methodology, J.-W.Z., T.-Q.H. and Q.Y.; validation, J.-W.Z., T.-Q.H. and Q.Y.; formal analysis, J.-W.Z. and T.-Q.H.; investigation, J.-W.Z. and T.-Q.H.; resources, H.-H.L. and L.Y.; data curation, J.-W.Z., T.-Q.H. and Q.Y.; writing—original draft preparation, J.-W.Z. and T.-Q.H.; writing-review and editing, H.-H.L. and L.Y.; visualization, J.-W.Z., T.-Q.H. and Q.Y.; supervision, H.-H.L. and L.Y.; project administration, H.-H.L. and L.Y.; funding acquisition, H.-H.L. and L.Y. All authors have read and agreed to the published version of the manuscript.

Funding: This research was funded by the National Natural Science Foundation of China (Grant No. 31870545) and Key Laboratory of Bio-based Material Science and Technology (Northeast Forestry University), Ministry of Education (SWZ-MS201903).

Conflicts of Interest: The authors declare no conflict of interest.

\section{References}

1. Kasemsiri, P.; Hiziroglu, S.; Rimdusit, S. Characterization of heat treated eastern redcedar (Juniperus virginiana L.). J. Mater. Process. Technol. 2012, 212, 1324-1330. [CrossRef]

2. Korkut, D.S.; Hiziroglu, S. Experimental Test of Heat Treatment Effect on Physical Properties of Red Oak (Quercus falcate Michx.) and Southern Pine (Pinus taeda L.). Materials 2014, 7, 7314-7323. [CrossRef] [PubMed]

3. Okon, K.E.; Lin, F.; Chen, Y.; Huang, B. Effect of silicone oil heat treatment on the chemical composition, cellulose crystalline structure and contact angle of Chinese parasol wood. Carbohydr. Polym. 2017, 164, 179-185. [CrossRef] 
4. He, Z.; Qian, J.; Qu, L.; Yan, N.; Yi, S. Effects of Tung oil treatment on wood hygroscopicity, dimensional stability and thermostability. Ind. Crops Prod. 2019, 140, 111647. [CrossRef]

5. Sun, S.; Zhao, Z.; Umemura, K. Further exploration of sucrose-citric acid adhesive: Synthesis and application on plywood. Polymers 2019, 11, 1875. [CrossRef]

6. Rautkari, L.; Hill, C.A.S.; Curling, S.; Jalaludin, Z.; Ormondroyd, G. What is the role of the accessibility of wood hydroxyl groups in controlling moisture content? J. Mater. Sci. 2013, 48, 6352-6356. [CrossRef]

7. Hill, C.A.S.; Ramsay, J.; Keating, B.; Laine, K.; Rautkari, L.; Hughes, M.; Constant, B. The water vapour sorption properties of thermally modified and densified wood. J. Mater. Sci. 2011, 47, 3191-3197. [CrossRef]

8. Esteves, B.; Graça, J.; Pereira, H. Extractive composition and summative chemical analysis of thermally treated eucalypt wood. Holzforschung 2008, 62, 344-351. [CrossRef]

9. Broda, M.; Mazela, B. Application of methyltrimethoxysilane to increase dimensional stability of waterlogged wood. J. Cult. Herit. 2017, 25, 149-156. [CrossRef]

10. Ayrilmis, N. Combined effects of boron and compatibilizer on dimensional stability and mechanical properties of wood/HDPE composites. Compos. Pt. B-Eng. 2013, 44, 745-749. [CrossRef]

11. Liu, W.; Hu, C.; Zhang, W.; Liu, Z.; Shu, J.; Gu, J. Modification of birch wood surface with silane coupling agents for adhesion improvement of UV-curable ink. Prog. Org. Coat. 2020, 148, 105833. [CrossRef]

12. Mattos, B.D.; Lourençon, T.V.; Serrano, L.; Labidi, J.; Gatto, D.A.; Serrano, L. Chemical modification of fast-growing eucalyptus wood. Wood Sci. Technol. 2015, 49, 273-288. [CrossRef]

13. Gu, L.; Ding, T.; Jiang, N. Development of wood heat treatment research and industrialization. J. For. Eng. 2019, 4, 1-11. [CrossRef]

14. Hosseinpourpia, R.; Adamopoulos, S.; Holstein, N.; Mai, C. Dynamic vapour sorption and water-related properties of thermally modified Scots pine (Pinus sylvestris L.) wood pre-treated with proton acid. Polym. Degrad. Stab. 2017, 138, 161-168. [CrossRef]

15. Wang, W.; Zhu, Y.; Cao, J.; Guo, X. Thermal modification of Southern pine combined with wax emulsion preimpregnation: Effect on hydrophobicity and dimensional stability. Holzforschung 2015, 69, 405-413. [CrossRef]

16. Humar, M.; Krzišnik, D.; Lesar, B.; Thaler, N.; Ugovšek, A.; Zupancic, K.; Zlahtic, M. Thermal modification of wax-impregnated wood to enhance its physical, mechanical, and biological properties. Holzforschung 2017, 71, 57-64. [CrossRef]

17. Yildiz, S.; Gezer, E.D.; Yildiz, U.C. Mechanical and chemical behavior of spruce wood modified by heat. Build. Environ. 2006, 41, 1762-1766. [CrossRef]

18. Hu, J.; Liu, Y.; Wu, Z.H. Structural Color for Wood Coloring: A Review. BioResources 2020, 4, 9917-9934. [CrossRef]

19. Schultz, T.P.; Nicholas, D.D.; Ingram, L.L. Laboratory and outdoor water repellency and dimensional stability of southern pine sapwood treated with a waterborne water repellent made from resin acids. Holzforschung 2007, 61, 317-322. [CrossRef]

20. Kaldun, C.; Dahle, S.; Maus-Friedrichs, W.; Namyslo, J.C.; Kaufmann, D.E. Chemical improvement of surfaces. Part 4: Significantly enhanced hydrophobicity of wood by covalent modification with p-silyl-functionalized benzoates. Holzforschung 2016, 70, 411-419. [CrossRef]

21. Chau, T.; Ma, E.; Cao, J. Moisture Adsorption and Hygroexpansion of Paraffin Wax Emulsion-treated Southern Pine (Pinus spp.). Bioresources 2015, 10, 2719-2731. [CrossRef]

22. Scholz, G.; Krause, A.; Militz, H. Exploratory study on the impregnation of Scots pine sapwood (Pinus sylvestris L.) and European beech (Fagus sylvatica L.) with different hot melting waxes. Wood Sci. Technol. 2010, 44, 379-388. [CrossRef]

23. Wang, J.; Zhong, H.; Ma, E.; Cao, J. Properties of wood treated with compound systems of paraffin wax emulsion and copper azole. Eur. J. Wood Wood Prod. 2016, 76, 315-323. [CrossRef]

24. Papadopoulos, A.N.; Pougioula, G. Mechanical behaviour of pine wood chemically modified with a homologous series of linear chain carboxylic acid anhydrides. Bioresour. Technol. 2010, 101, 6147-6150. [CrossRef] [PubMed]

25. Xie, Y.; Fu, Q.; Wang, Q.; Xiao, Z.; Militz, H. Effects of chemical modification on the mechanical properties of wood. Eur. J. Wood Wood Prod. 2013, 71, 401-416. [CrossRef] 
26. Scholz, G.; Militz, H.; Gascón-Garrido, P.; Ibiza-Palacios, M.S.; Oliver-Villanueva, J.V.; Peters, B.C.; Fitzgerald, C.J. Improved termite resistance of wood by wax impregnation. Int. Biodeterior. Biodegrad. 2010, 64, 688-693. [CrossRef]

27. Li, Y.; Li, X.; Huang, Q.; Wu, Y.; Li, X.; Chen, Z. Impregnation with Microcrystalline Wax to Improve Rosewood Dimensional Stability and Surface Hardness. BioResources 2015, 10, 5994-6000. [CrossRef]

28. Zhou, Y.; Xue, Z.; Huang, Q.; Yao, B.; Wang, X. Physical and mechanical properties of Aucoumea klaineana wood after vacuum heat treatment for furniture components. J. For. Eng. 2020, 4, 73-78. [CrossRef]

29. Zhang, J.; Chesnokova, T.; Zhang, B.; Zhan, J. Chromatic variability of larch wood impacted by high-temperature thermal treatment and oil-wax coating. J. For. Eng. 2020, 6, 64-75. [CrossRef]

30. Wang, W.; Ran, Y.; Wang, J. Improved performance of thermally modified wood via impregnation with carnauba wax/organoclay emulsion. Constr. Build. Mater. 2020, 247, 118586. [CrossRef]

31. Candelier, K.; Dumarcay, S.; Pétrissans, A.; Gérardin, P.; Pétrissans, M. Comparison of mechanical properties of heat treated beech wood cured under nitrogen or vacuum. Polym. Degrad. Stab. 2013, 98, 1762-1765. [CrossRef]

32. Ding, T.; Peng, W.; Li, T. Mechanism of color change of heat-treated white ash wood by means of FT-IR and XPS analyses. J. For. Eng. 2017, 5, 25-30. [CrossRef]

33. Surini, T.; Charrier, F.; Malvestio, J.; Charrier, B.; Moubarik, A.; Castera, P.; Grelier, S. Physical properties and termite durability of maritime pine pinus pinaster ait. heat-treated under vacuum pressure. Wood Sci. Technol. 2012, 46, 487-501. [CrossRef]

34. Rasdianah, D.; Zaidon, A.; Hidayah, A.; Lee, S.H. Effects of superheated steam treatment on the physical and mechanical properties of light red meranti and kedondong wood. J. Trop. For. Sci. 2018, 30, 384-392. [CrossRef]

35. Kocaefe, D.; Poncsak, S.; Boluk, Y. Effect of thermal treatment on the chemical composition and mechanical properties of birch and aspen. BioResources 2008, 3, 517-537. [CrossRef]

36. Shi, J.L.; Kocaefe, D.; Zhang, J. Mechanical behaviour of Québec wood species heat-treated using ThermoWood process. Holz. Roh. Werkst. 2007, 65, 255-259. [CrossRef]

Publisher's Note: MDPI stays neutral with regard to jurisdictional claims in published maps and institutional affiliations.

(C) 2020 by the authors. Licensee MDPI, Basel, Switzerland. This article is an open access article distributed under the terms and conditions of the Creative Commons Attribution (CC BY) license (http://creativecommons.org/licenses/by/4.0/). 